\title{
Eye hue and the oculocardiac reflex
}

\author{
E. N. S. FRY AND J. B. HALL-PARKER
}

From the Departments of Anaesthesia and Ophthalmology, North Tees General Hospital, Stockton-on-Tees

SUMMARY During operations for squint nodal rhythm and other more serious arrhythmias such as heart block and multifocal ventricular extrasystoles, as well as the oculocardiac reflex, are shown to occur more frequently in patients with brown or hazel eyes than in patients with blue or grey eyes.

The oculocardiac reflex is a slowing of the heart caused by various stimuli especially pressure on the lateral part of the eyeball and traction on the medial rectus muscle. It occurs during the majority of operations for squint (Bosomworth et al., 1958; Deacock and Oxer, 1962). Previous work by the authors indicated that the incidence of the reflex is related to the eye hue (Fry and Hall-Parker, 1975). The purpose of this study is to confirm this finding and to show that the incidence of nodal rhythm and other more serious cardiac irregularities is also related to the eye hue.

\section{Patients and methods}

Three hundred and sixty-three consecutive patients whose squints were treated by medial rectus recession or resection were studied.

\section{ANAESTHETIC TECHNIQUE}

Patients over 12 years old were given papaveretum $10 \mathrm{mg}$, prochlorperazine $12.5 \mathrm{mg}$, and atropine $0.6 \mathrm{mg}$ intramuscularly an hour before operation. General anaesthesia was induced by Althesin 3 to $5 \mathrm{ml}$ and suxamethonium 20 to $50 \mathrm{mg}$, and after oral intubation maintained by nitrous oxide, oxygen, and halothane $1 \%$. Patients under 12 years old were given trimeprazine orally $3 \mathrm{mg} / \mathrm{kg}$ body weight up to $32 \mathrm{~kg}$, and atropine $0.4 \mathrm{mg}$ if less than $20 \mathrm{~kg}$ body weight and atropine $0.6 \mathrm{mg}$ if over that weight, 90 minutes before operation. Anaesthesia was induced and maintained by nitrous oxide, oxygen, and halothane $1 \%$ using a Jackson Rees modification of an Ayre's T-piece.

RECORDING THE REFLEX

The heart rate and electrocardiograph (ECG) trace of the first 198 patients were monitored on a

Address for reprints: Dr E. N. S. Fry, Department of Anaesthesia, North Tees General Hospital, Hardwick, Stockton-on-Tees, Cleveland TS19 8PE
Cardiorater; the remainder had ECG recordings taken from the lead 2 of a Cambridge Transrite 2 in addition. The reflex was deemed to be present if the heart rate fell by 10 beats per minute or more after the first retraction of the medial rectus muscle.

\section{EYE HUE}

The patients were placed into 4 groups relating to the eye hue: blue, grey, hazel, and brown. Eye hues were determined under the same strip lighting by a consensus of nursing staff present in the anaesthetic room before the operation was begun.

\section{Results}

Table 1 shows the incidence of the oculocardiac reflex following the first retraction of the medial rectus muscle $(P=<0.001)$, and the incidence of sinus and nodal rhythms in the patients developing bradycardia $(P=<0.01)$.

Table 2 shows the range of cardiac slowing in the cases developing sinus bradycardia and in the cases developing nodal rhythm in association with bradycardia. There is no significant difference between the two groups.

Table 1 Presence of sinus bradycardia, nodal rhythm, and oculocardiac reflex (with percentages in parentheses)

\begin{tabular}{llllllllll}
\hline Eye hue & Total & $\begin{array}{l}\text { Mean } \\
\text { age }\end{array}$ & $\begin{array}{l}\text { Sinus } \\
\text { bradycardia }\end{array}$ & $\begin{array}{l}\text { Nodal } \\
\text { rhythm* }\end{array}$ & \multicolumn{2}{l}{$\begin{array}{l}\text { Oculocardiac } \\
\text { reflex } \dagger\end{array}$} \\
\hline Blue & 128 & 8.91 & 28 & $(21.9)$ & 36 & $(28 \cdot 1)$ & 64 & $(50 \cdot 0)$ \\
Grey & 89 & 8.94 & 35 & $(39 \cdot 2)$ & 31 & $(34 \cdot 7)$ & 66 & $(73.9)$ \\
Hazel & 78 & 10.39 & 14 & $(18.0)$ & 51 & $(65.4)$ & 65 & $(83.4)$ \\
Brown & 68 & 8.85 & 21 & $(30.9)$ & 37 & $(54.4)$ & 58 & $(85 \cdot 3)$ \\
Total & 363 & 9.22 & 98 & $(27.0)$ & 155 & $(42.7)$ & 253 & $(69 \cdot 7)$ \\
\hline
\end{tabular}

$\chi^{2}=33 \cdot 58, \mathrm{DF}=3, \mathrm{P}<0.001$

$+x^{2}=39 \cdot 0, D F=3, P<0.001$ 
Table 2 Incidence of nodal and sinus rhythms related to degree of bradycardia

\begin{tabular}{lllllllllll}
\hline $\begin{array}{c}\text { Maximal } \\
\text { slowing } \\
\text { of heart: } \\
\text { beats/ } \\
\text { minute }\end{array}$ & $0-10$ & $11-20$ & $21-30$ & $31-40$ & $41-50$ & $51-60$ & $61-70$ & 80 & Total \\
$\begin{array}{l}\text { Nodal } \\
\text { rhythms }\end{array}$ & 7 & 47 & 36 & 29 & 18 & 13 & 3 & 2 & 155 \\
$\begin{array}{l}\text { Sinus } \\
\text { rhythms }\end{array}$ & 5 & 27 & 17 & 17 & 15 & 10 & 5 & 2 & 98 \\
\hline
\end{tabular}

Correlation coefficient $0 \cdot 97 . \quad \chi^{2}$ test no significance

Table 3 Mean and standard deviation (parentheses) of degree of bradycardia related to eye hue and type of rhythm, with the mean and standard deviation of the mean heart rate at the point of slowest beat and the incidence of extrasystoles and other arrhythmias

\begin{tabular}{|c|c|c|c|c|c|c|c|}
\hline \multirow{2}{*}{$\frac{\text { Eye hue }}{\text { Blue }}$} & \multirow{2}{*}{$\begin{array}{l}\text { Rhythm } \\
\text { Sinus } \\
\text { Nodal }\end{array}$} & \multirow{2}{*}{$\begin{array}{l}\begin{array}{l}\text { No. of } \\
\text { cases }\end{array} \\
28 \\
36\end{array}$} & \multicolumn{2}{|c|}{$\begin{array}{l}\text { Mean } \\
\text { slowing }\end{array}$} & \multicolumn{2}{|c|}{$\begin{array}{l}\text { Mean rate at } \\
\text { maximal } \\
\text { slowing }\end{array}$} & \multirow{2}{*}{$\begin{array}{l}\begin{array}{l}\text { Extra } \\
\text { systoles }\end{array} \\
\begin{array}{l}0 \\
2\end{array}\end{array}$} \\
\hline & & & $\begin{array}{l}37 \cdot 2 \\
32 \cdot 2\end{array}$ & $\begin{array}{l}( \pm 17 \cdot 0) \\
( \pm 20 \cdot 0)\end{array}$ & $\begin{array}{l}88 \cdot 6 \\
88.9\end{array}$ & $\begin{array}{l}( \pm 22 \cdot 8) \\
( \pm 24 \cdot 9)\end{array}$ & \\
\hline Grey & $\begin{array}{l}\text { Sinus } \\
\text { Nodal }\end{array}$ & $\begin{array}{l}35 \\
31\end{array}$ & $\begin{array}{l}34 \cdot 0 \\
33 \cdot 9\end{array}$ & $\begin{array}{l}( \pm 16 \cdot 1) \\
( \pm 16 \cdot 9)\end{array}$ & $\begin{array}{l}81 \cdot 2 \\
83 \cdot 7\end{array}$ & $\begin{array}{l}( \pm 23 \cdot 6) \\
( \pm 23 \cdot 3)\end{array}$ & $\begin{array}{l}1 \\
4\end{array}$ \\
\hline Hazel & $\begin{array}{l}\text { Sinus } \\
\text { Nodal }\end{array}$ & $\begin{array}{l}14 \\
51\end{array}$ & $\begin{array}{l}39 \cdot 2 \\
34 \cdot 1\end{array}$ & $\begin{array}{l}( \pm 18 \cdot 2) \\
( \pm 13 \cdot 6)\end{array}$ & $\begin{array}{r}100 \cdot 6 \\
79 \cdot 8\end{array}$ & $\begin{array}{l}( \pm 24 \cdot 4) \\
( \pm 24 \cdot 0)\end{array}$ & $\begin{array}{l}1 \\
6\end{array}$ \\
\hline Brown & $\begin{array}{l}\text { Sinus } \\
\text { Nodal }\end{array}$ & $\begin{array}{l}21 \\
37\end{array}$ & $\begin{array}{l}40 \cdot 9 \\
35 \cdot 0\end{array}$ & $\begin{array}{l}( \pm 19 \cdot 5) \\
( \pm 15 \cdot 6)\end{array}$ & $\begin{array}{l}79 \cdot 3 \\
84 \cdot 2\end{array}$ & $\begin{array}{l}( \pm 22 \cdot 0) \\
( \pm 28 \cdot 0)\end{array}$ & $\begin{array}{l}0 \\
7\end{array}$ \\
\hline
\end{tabular}

The frequency of extrasystoles and other arrhythmias related to eye hue is significant. $\chi^{2}$ test and Fisher's exact test give $\mathbf{P}=<0.05$. There is no significant difference ( $\chi^{2}$ test) between the mean slowing of the heart rate related to the mean rate at maximal slowing in the various groups

Table 3 shows the range of cardiac slowing and the mean minimum heart rate in the various groups of patients that developed the reflex. There is no significant difference between any of these groups. The figures in the last column indicate that patients with blue eyes are less likely to develop the more serious arrhythmias such as multifocal ventricular extrasystoles, heart block (1 case), and auriculoventricular dissociation ( 1 case) than are patients with brown or hazel eyes $(P=<0.05)$.

\section{Discussion}

The increased incidence of oculocardiac reflex in patients with brown or hazel eyes compared with those with blue or grey eyes (Fry and Hall-Parker, 1975) has been confirmed. These results indicate that, while pulse or ECG monitoring should be performed during general anaesthesia for any ophthalmic operation, special vigilance should be exercised if a muscle is retracted or pressure placed upon the eyeball of a hazel- or brown-eyed patient.

Nodal rhythm, extrasystoles, and other abnormal cardiac rhythms occur more often during the oculocardiac reflex in patients with hazel and brown eyes than those with blue or grey eyes. There is no evidence from these figures that this difference is caused by more severe bouts of bradycardia or a raising of the threshold of nodal escape during the relevant periods. Since the incidence of nodal rhythm and other arrhythmias in the various groups is not related to the incidence of the oculocardiac reflex or to the degree of cardiac slowing that is induced, occurring significantly more often than expected in patients with brown or hazel eyes, the authors postulate that there may be more than one mechanism involved in producing the oculocardiac reflex. This effect may act on the neural pathways at any level between the muscles of the eye and the conducting fibres of the heart. It would be interesting to see if the incidence of arrhythmias developing in patients suffering from cardiac damage, especially coronary thombosis, shows a similar relation to eye hue. If so, the colour of the eye could become a factor in the selection of patients for intensive coronary care.

We thank Mrs J. D. Cranage of the Northern Regional Health Authority for performing the statistical calculations.

\section{References}

Bosomworth, P. P., Ziegler, C. H., and Jacoby, J. (1958). The oculocardiac reflex. Anesthesiology, 19, 7-10.

Deacock, A. R. de C., and Oxer, H. F. (1962). The prevention of reflex bradycardia during ophthalmic surgery. British Journal of . Anaesthesia, 34, 451-457.

Fry, E. N. S., and Hall-Parker, J. B. (1975). Hyoscine butyl bromide and the oculocardiac reflex. British Journal of Ophth.slmology, 59, 525. 